\title{
Same but different
}

DOI:

10.1038/nrn1960

URLs

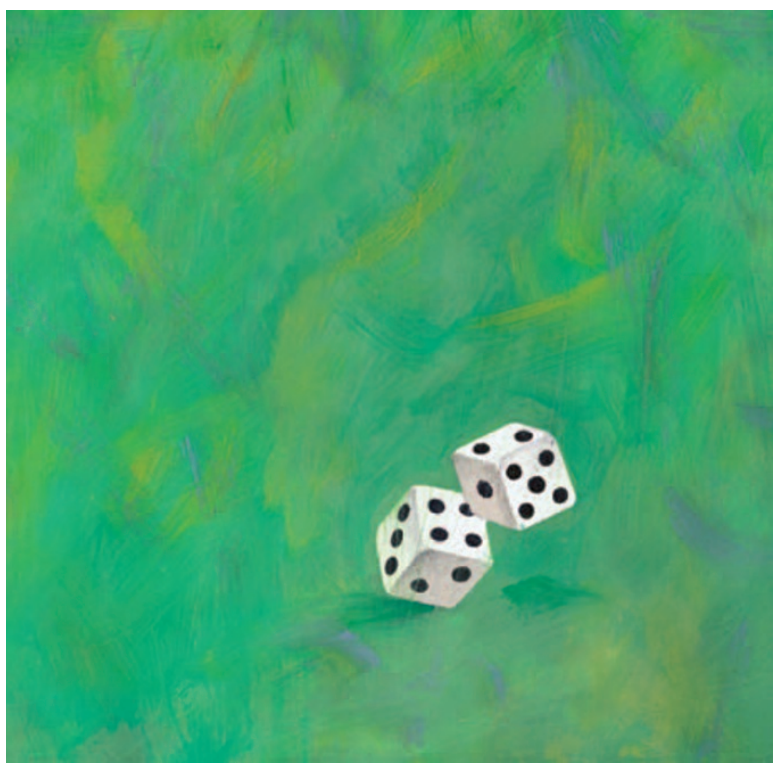

in which $\mathrm{GABA}_{\mathrm{B} 1 \mathrm{a}}$ and $\mathrm{GABA}_{\mathrm{B} 1 \mathrm{~b}}$ were inactivated one at a time. Electron microscopy studies showed that, in the hippocampus, $\mathrm{GABA}_{\mathrm{Bla}}$ was predominantly localized at glutamatergic terminals, whereas $\mathrm{GABA}_{\mathrm{B} 1 \mathrm{~b}}$ was mainly found at dendritic spines opposite to the glutamate release sites. This differential localization of $\mathrm{GABA}_{\mathrm{B} 1}$ isoforms correlated with their functional differences: at hippocampal CA3-to-CA1 synapses, $\mathrm{GABA}_{\mathrm{Bla}}$ assembled receptors that blocked presynaptic glutamate release, while $\mathrm{GABA}_{\mathrm{B} 1 \mathrm{~b}}$ was involved in postsynaptic inhibition of neuronal firing. Intriguingly, the constitutive absence of $\mathrm{GABA}_{\mathrm{B} 1 \mathrm{a}}$, but not $\mathrm{GABA}_{\mathrm{B} 1 \mathrm{~b}}$, resulted in impaired synaptic plasticity and hippocampus-dependent memory formation. This suggests that different $\mathrm{GABA}_{\mathrm{B}}$ receptor compositions might mediate distinct neural functions.

In a companion paper, PerezGarci and colleagues report similar results of distinct $\mathrm{GABA}_{\mathrm{B} 1}$ receptor functions in pyramidal neurons residing in layer 5 (L5) of the neocortex. These L5 neurons are innervated by numerous inhibitory inputs, including those from interneurons in L1. The researchers first established that extracellular stimulation of L1 inhibited the dendritic $\mathrm{Ca}^{2+}$ spikes in L5 pyramidal neurons. Further, the short-lasting component of this inhibitory effect was mediated by $\mathrm{GABA}_{\mathrm{A}}$ receptors, whereas the long-term counterpart was mediated by $\mathrm{GABA}_{\mathrm{B}}$ receptors. Using the knockout mice generated by Bettler et al., the researchers found that L5 pyramidal neurons from $\mathrm{GABA}_{\mathrm{Bla}^{-}}$deficient mice showed normal short- and long-lasting inhibitory components in response to L1 stimulation. By contrast, the absence of $\mathrm{GABA}_{\mathrm{B} 1 \mathrm{~b}}$ completely abolished the long-term inhibitory response of L5 pyramidal neurons, but the $\mathrm{GABA}_{\mathrm{A}}$ mediated short-term inhibition was unaffected.

These two studies shed fresh light on the apparent contradiction between functional diversity and molecular simplicity of the GABA $_{B}$ receptor system. It will be interesting to test whether other GABA receptors deploy similar strategies to generate distinct activity under different physiological conditions.

Jane Qiu

ORIGINAL RESEARCH PAPERS Vigot, R. et al. Differential compartmentalization and distinct functions of $\mathrm{GABA}_{\mathrm{B}}$ receptor vaiants. Neuron $\mathbf{5 0}$, 589-601 (2006) | Perez-Garci, E. et al. The GABA isoform mediates long-lasting inhibition of dendritic $\mathrm{Ca}^{2+}$ spikes in layer 5 somatosensory pyramidal neurons. Neuron 50, 603-616 (2006) FURTHER READING Farrant, M. \& Nusser, Z. Variations on an inhibitory theme: phasic and tonic activation of GABA $A_{A}$ receptors. Nature Rev. Neurosci. 6, 215-229 (2005) WEB SITES

Bettler's laboratory:

http://www.pharmazentrum.unibas.ch/bettler.htm Larkum's laboratory:

http://pylwww.unibe.ch/ larkum/ 